\title{
The Remuneration of Independent Directors in the UK and Italy: An empirical analysis based on agency theory
}

\author{
Chris Mallin \\ University of East Anglia \\ Andrea Melis \\ Silvia Gaia \\ University of Cagliari
}

Accepted for publication at International Business Review ( $2^{\text {nd }}$ July 2014) 


\title{
The Remuneration of Independent Directors in the UK and Italy: An empirical analysis based on agency theory
}

\begin{abstract}
This study investigates independent non-executive directors' remuneration from an agency theory perspective, taking into account both optimal contracting and managerial power perspectives. Using a sample of 1733 independent non-executive directors' year observations in Italian and UK non-financial firms listed in the period 2007-2009, we find that in both countries independent non-executive directors' remuneration is mainly based on the observable effort they exert and their responsibilities. Our findings also show that independent non-executive directors who do not fulfil formal independence criteria, as stated in the respective national corporate governance codes, seem to be paid more than those who do fulfil such criteria, particularly in the UK.

Our findings contribute to the existing literature by providing evidence on the determinants of independent non-executive directors' remuneration in two major European economies and offer insights to policy-makers by questioning the effectiveness of adopting non-binding criteria when assessing non-executive directors' independence.
\end{abstract}

Keywords: corporate governance; independent non-executive director; remuneration; agency theory, Italy; UK 


\section{The Remuneration of Independent Directors in the UK and Italy: An empirical analysis based on agency theory}

\section{Introduction}

Independent non-executive directors (hereafter INEDs) are expected to act as monitors of, and advisors to, executive directors on behalf of shareholders (Fama \& Jensen, 1983). INEDs represent a key corporate governance mechanism and their presence on the board of directors and on the board committees is a commonly recommended governance practice (Zattoni \& Cuomo, 2010). Although it has been argued that candidates may be attracted to INED positions for other than pecuniary reasons (Fama \& Jensen, 1983; Mace, 1971: 109; Lorsch \& MacIver 1989: 30), empirical evidence has shown that remuneration is an essential factor for INEDs (Adams \& Ferreira, 2008; Certo, Dalton, Dalton \& Lester, 2008).

On the one hand, INEDs' remuneration signals the quality and effectiveness of INEDs in performing their roles. INEDs are facing increasing duties and legal responsibilities, the demand for effective supervision by INEDs being reflected in the latest regulatory initiatives in various countries (Lazar, Metzner, Rapp \& Wolff, 2014). This increase in INEDs' duties and legal responsibilities leads not only to a greater time commitment but also exposes INEDs to a greater reputational risk. High levels of INEDs' remuneration could reflect the time commitment (Adams \& Ferreira, 2008) and reputational risk that accompanies the INEDs role (e.g., Linck, Netter \& Yang, 2009; Aguir, Burns, Mansi \& Wald, 2014). On the other hand, INEDs' remuneration might also reveal INEDs' ineffectiveness because of the potential reciprocity between INEDs and corporate insiders where ineffective monitoring makes corporate insiders 
more inclined towards INEDs' remuneration increases (Bebchuk, Fried \& Walker, 2002). From this perspective, INEDs' remuneration could represent a "reward" for ineffective monitoring actions resulting from the collusion between INEDs and corporate insiders. Therefore understanding more about INEDs' remuneration is particularly important. However, despite its theoretical and practical relevance, the remuneration of INEDs has received little attention so far and has been referred as an "enigma" (Hahn \& Lasfer, 2011; Magnan, St-Onge \& Gélinas, 2010), regarding both the amount and the design (Shen, 2005; Brown, 2007; Magnan et al., 2010). In this paper we help to fill this lacuna in the literature.

Most of the literature on corporate governance, including the studies on the design and level of directors' remuneration, mainly relies on agency theory (e.g., Tosi \& Gomez-Mejia, 1989; Jensen \& Murphy, 1990; Cordeiro, Veliyath \& Eramus, 2000; Fernandes, Ferreira, Matos \& Murphy, 2013). This study aims at investigating to what extent agency theory can explain INEDs' remuneration in different contexts, taking into account both an optimal contracting view and a managerial power perspective. In particular it considers the potential determinants of INEDs' remuneration as being the INEDs' effort and responsibilities that are observable by shareholders and also the INEDs' potential conflicts of interest where the formal independence criteria, as embodied in the corporate governance codes, have not been adhered to.

The paper makes a number of key contributions to the existing body of knowledge. First, it provides new insights on the determinants of INEDs' remuneration, in particular the criteria by which INEDs are remunerated, which is an important issue given the potential for agency problems between boards of directors and shareholders (Bebchuk et al., 2002; Certo et al., 2008; 
Andreas, Rapp \& Wolff, 2012). In particular, by analysing the influence played by INEDs' observable effort/responsibilities and/or the conflicts of interest in their remuneration in Europe, we extend the scant literature which is mainly focused on the debate in North America on whether the pay-for-performance principles for rewarding executive directors are applicable to INEDs (e.g., Hempel \& Fay, 1994; Cordeiro et al., 2000; Yermack, 2004; Ronen, Tzur \& Yaari, 2006; Magnan et al., 2010). Given the characteristics of the INEDs' job as well as the recommendations by most corporate governance codes in Europe (e.g., UK Corporate Governance Code, 2012; Italian Code of Conduct, 2006, 2011; Dutch Corporate Governance Code, 2008; Spanish Unified Good Governance Code, 2006; ICGN, 2010) investigating whether INEDs' remuneration reflects their effort and responsibilities and/or rather a conflict of interest becomes relevant as it provides an understanding as to what extent INEDs' remuneration reflects an optimal contracting perspective or a managerial power perspective of agency theory. In line with the Van Essen, Otten, and Carberry (2014) study on executive remuneration, we find that optimal contracting and managerial power perspectives seem to provide complementary, rather than competing, explanations to INED's remuneration, as they encompass different contracting arrangements covered by agency theory.

Second, by conducting a study on two institutional settings, Italy and the UK, that can be characterised as opposite ends of a spectrum in terms of their corporate governance practices, we investigate whether agency theory can be applied to very different contexts (e.g., Bowe, Filatotchev, Marshall, 2010; Cho, Huang \& Padmanabhan, 2014). Critics of agency theory have pointed out its under-contextualized nature, and hence its inability to accurately compare and explain the diversity of corporate governance practices across different institutional contexts 
(e.g., Aguilera \& Jackson, 2003; Van Essen, Heugens, Otten \& Van Oosterhout, 2012). In this vein, Aguilera, Filatotchev, Gospel \& Jackson (2008) argue that a 'closed-system approach' within agency theory posits a universal set of relationships between corporate governance practices and devotes little attention to the distinct contexts in which firms are embedded. However, supporters of agency theory argue that agency theory does not necessarily rule out institutional factors (e.g., Eisenhardt, 1988; Bender, 2004; Wiseman, Cuevas-Rodríguez \& Gomez-Mejia, 2012). Despite the fact that agency problems (such as information asymmetry, conflicts of interest, and opportunistic agent's behaviour) are universal, as long as delegation is involved, their explicit manifestation and the ways to deal with them may vary depending on institutional context (Wiseman et al., 2012). Agency contracts are socially embedded such that differences in the institutional contexts surrounding the principal-agent relation can affect the form of governance that is used (Wiseman et al., 2012).

Third, the choice of these institutional settings answers the call of Aguilera and Cuervo-Cazurra (2009) for a more careful examination of what each Code of Corporate Governance contains to understand the soundness of its recommendations as they are not homogeneous in content. In contrast with most of the corporate governance codes in Europe (e.g., Spanish Unified Good Governance Code, 2006; Austrian Code of Corporate Governance, 2009; German Corporate Governance Code, 2009) that have adopted a rules-based approach by requiring companies to consider a non-executive director to be independent only when several criteria are met, Italy and the UK are both countries whose corporate governance codes allow companies to deem a director as independent notwithstanding that all the independence criteria stated by the Codes are not fulfilled (Italian Code of Conduct, 2006; 2011; UK Corporate Governance Code, 2012). In 
such cases companies should explain this decision in the corporate governance report. This unique approach allows us to analyse the potential differences, in terms of overall remuneration as well as the relation with INEDs' effort and responsibilities, amongst the INEDs who fulfil all the independence criteria and those who do not.

The paper is structured as follows. The next section provides some background on the institutional settings for INEDs' remuneration in Italy and the UK. This is followed by the literature review and hypotheses' development. We then describe the research methodology, followed by the findings. Discussion of the results, concluding remarks and the limitations of the study are presented in the final section.

\section{Institutional settings}

The settings of Italy and the UK were chosen on the basis that important differences exist between the two corporate governance systems (Melis, 2000). Comparing institutional settings characterized by such diversity in corporate governance practices should enhance the potential generalizability of the findings, by allowing account to be taken of the potential variation existing in governance practices in firms that operate in highly developed countries (e.g., Minichilli, Zattoni, Nielsen \& Huse 2012). Italy is representative of the Latin civil law based 'insider-oriented' corporate governance system, while the UK is an example of the AngloAmerican market-based outsider-oriented common law system (Weimer \& Pape, 1999). Although Italian and UK firms operate in some of the largest and most developed economies, UK firms are often considered as having the best corporate governance practices in Europe (RiskMetrics, 2009; Heidrick \& Struggles, 2009), while Italian firms have often been taken as an 
example of bad corporate governance practices (La Porta, Lopez de Silanes, Shleifer \& Vishny, 1997; Johnson, La Porta, Lopez-De-Silanes \& Shleifer, 2000, Volpin, 2002).

Moreover, UK listed firms are usually characterised by a principal-agent problem (Mallin, 2010), while Italian listed firms are characterized by a principal-principal agency problem (Melis, 2000), and different agency problems might have a different influence on remuneration practices (Bebchuk et al., 2002; Filatotchev \& Allcock, 2010) as well as on the role of INEDs (Johanson \& Østergren, 2010).

\subsection{Italy}

Italian non-financial listed firms are characterised by the presence of a controlling shareholder who is able to monitor directors (Melis, 2000; Volpin, 2002). His/her presence reduces the agency problem between executive directors and shareholders, but gives rise to the principalprincipal agency problem between the controlling shareholder and minority shareholders (Zattoni 1999; Melis, 2000). The appointment of an adequate number of INEDs to the board has been considered as a solution 'for guaranteeing the composition of the interests of all the shareholders, both majority and minority ones' (Italian Code of Conduct, 2006; 2011). The Italian Code of Conduct provisions regarding non-executive director independence are detailed and compared with those of the UK Corporate Governance Code in Table 1. Nonetheless, the independence criteria are not binding for the board which can adopt additional or different criteria to assess non-executive director independence. 
The Italian Code of Conduct $(2006 ; 2011)$ does not recommend appointing an INED as chairperson of the board, and such a position is often held by the controlling shareholder (Melis \& Gaia, 2011). To provide a balance of power with the non-independent chairperson, it recommends that a lead (senior) independent director (hereafter SID) should be appointed in those firms whose chairperson is also the $\mathrm{CEO}$ and/or the controlling shareholder.

The Italian Code of Conduct $(2006$; 2011) recommends that INEDs' remuneration should not be linked - other than for a non-significant portion - to firm performance. Receiving significant additional remuneration, compared to the 'fixed' remuneration of other non-executive directors, and/or being a beneficiary of a share-based plan, are considered situations that could affect nonexecutive directors' independence. Remuneration should be proportionate to the commitment required by each director, also taking into account his/her participation in board committees.

\subsection{The UK}

The Cadbury Report (1992) emphasized the contribution that INEDs could make, stating that 'the calibre of the non-executive members of the board is of special importance in setting and maintaining standards of corporate governance' (para 4.10). The UK Corporate Governance Code (2012) continues this view, placing much emphasis on the role of INEDs. The main board sub-committees (audit, remuneration and nomination) should be comprised of mainly, or wholly, INEDs. Section B.1.1 of the UK Corporate Governance Code defines the tests of independence for non-executive directors and these are detailed in Table 1, together with comparative independence criteria from the Italian Code of Conduct. In the context of smaller companies, section B.1.2 states that "except for smaller companies, at least half the board, excluding the 
chairman, should comprise non-executive directors determined by the board to be independent. A smaller company should have at least two INEDs.'

\section{INSERT TABLE 1}

In the UK, as in Italy, despite an individual not meeting these criteria the board could consider a non-executive director to be independent if $s($ he) can be considered to be 'independent in character and judgement'.

In relation to INEDs' remuneration, the UK Corporate Governance Code states that remuneration for non-executive directors should reflect their time commitment and responsibilities. It should not include share options or other performance-related elements. If, exceptionally, options are granted, shareholder approval should be sought in advance as holding share options could be relevant to the determination of a non-executive director's independence.

\section{Literature review and hypotheses development}

The limited research on INEDs' remuneration is either prescriptive (e.g., Brown, 2007; Magnan et al, 2010) or descriptive (e.g., Hahn and Lasfer, 2011; Lazar et al, 2014). Among the few empirical studies which are not descriptive, most rely on an economic approach based on an optimal contracting perspective of agency theory in a single institutional setting ${ }^{1}$. Those studies have mainly focused on the adoption of performance-based remuneration to reduce the potentially misaligned interest between shareholders and INEDs (e.g., Hempel and Fay, 1994; Boyd, 1996; Bryan, Hwang, Klein \& Lilien , 2000; Cordeiro et al., 2000) or the adoption of

\footnotetext{
${ }^{1}$ To our knowledge the only empirical study that adopts an alternative social-psychological approach to investigate the determinants of INEDs' remuneration is Marchetti and Stefanelli (2009).
} 
meeting fees to provide INEDs with an incentive to exert more effort (Hempel and Fay 1994; Bryan et al. 2000; Brick, Palmon \& Waldet, 2006; Farrell, Friesen \& Hersch, 2008; Adams and Ferreira 2008). A more comprehensive agency theory framework was adopted by Cordeiro et al. (2000), Andreas et al. (2012) and Marchetti \& Stefanelli (2009). These studies still rely on an optimal contracting perspective of agency theory, but consider not only firm performance and meeting fees as potential determinants of INEDs' remuneration but also INEDs' roles within the board and firm complexity.

Not only is agency theory the most adopted theoretical framework in the previous, albeit scant, academic literature but agency theory tends to dominate the recommendations on board best practices in the various codes of corporate governance (Zattoni \& Cuomo, 2010). Therefore, agency theory seems to provide an appropriate theoretical framework to investigate INEDs' remuneration.

Our study, in line with previous literature, develops its analysis focusing on the economic vision provided by agency theory. It extends previous literature by investigating agency theory from both an optimal contracting and a managerial power perspective in two very different institutional contexts - the UK and Italy. This choice allows us to deepen agency theory by complementing the economic approach provided by the optimal contracting view with a managerial power perspective, and to take into account whether the explicit manifestation and the ways to deal with agency problems vary depending on institutional context.

\section{Hypotheses' development}


Agency theory predicts that when dealing with non-programmable jobs where direct supervision is infeasible or counter-productive because of information asymmetries, i.e. when the agent has an information advantage over principals about the outcomes of his/her actions, it is efficient to write down a contract with payoffs that are based on outcomes that the principals can observe (Holmström, 1979). Hence, outcomes that can be measured more precisely and unequivocally can be expected to have greater influence over the distribution of rewards (Gomez-Mejia \& Balkin, 1992).

Following the logic of agency theory, in the board context the determination of INEDs' remuneration, in particular the criteria by which INEDs are remunerated, is an important issue given the potential for agency problems between boards of directors and shareholders (Bebchuk et al., 2002; Certo et al., 2008; Andreas et al, 2012). INEDs' work has low performance measurability, as the principal - the shareholders - is not likely to have the expertise to pass professional judgment on an INED's performance, given the extensive information asymmetries between the parties. The agency costs may be too high to allow the principal to monitor the quality of performance of an INED as an independent performance outcome. Hence, an INED's remuneration may depend heavily on observable measures, such as the effort and responsibilities of an INED that are visible by shareholders, in lieu of monitoring the INED's quality of performance.

In the same vein, determining INEDs' remuneration on the basis of their effort and responsibilities is in the interest of shareholders because firms that fail to do so would find it difficult to attract and retain talented directors (Hempel \& Fay, 1994; Cordeiro et al., 2000). 
Individuals seek to maintain an equilibrium between the inputs that they bring to a job and the outcomes they receive from it. Farrell et al. (2008) found that, contrary to the process for executive remuneration, INEDs' remuneration is set for a group of individuals as a whole, i.e. INEDs' remuneration is not designed based on the unique characteristics that a particular director brings to the board. According to this perspective, inter-directorial differences in remuneration may rather stem from taking on additional functions and responsibilities (e.g., chairmanship or committee membership) or variations in meeting attendance (Hempel \& Fay, 1994; Brick et al., 2006; Farrell et al., 2008; Marchetti \& Stefanelli, 2009), although Cordeiro et al. (2000) found mixed evidence between outside (non-executive) director's remuneration and measures of director's effort. However overall we would expect that the effort that an INED expends is usually directly related to his/her responsibilities in the board (Linck et al., 2009; Engel, Hayes \& Wang, 2010). Hence, we expect that:

H1: INED's remuneration will be positively related to the INED's observable efforts and responsibilities.

To pay INEDs considering the level of observable effort they exert and the responsibility they have on the board reflects an optimal contracting view. However, as in the case of CEO remuneration (e.g., Bebchuk et al., 2002), firms may adopt different criteria in setting INEDs' remuneration. The managerial power perspective (Bebchuk et al., 2002) starts with the recognition of an agency problem, and argues that just as there is no reason to assume that senior managers automatically seek to maximise shareholder value, there is no reason to expect that 
directors will either. Managerial power arises when the board is not independent (Bebchuk et al., 2002).

Directors with a potential conflict of interest, such as those who have a significant business relationship with the company, a family relationship with corporate insiders, or interlocking board memberships with the CEO, may not act in a truly independent manner (Yermack, 2004). Such directors could collude with corporate insiders, i.e. a sub-set of shareholders (e.g., the controlling shareholder) or the executive directors, and help those insiders in pursing their own interests rather those of shareholders. In such cases, the managerial power perspective suggests that directors who provide generosity to the corporate insiders find the latter reciprocating (Bebchuk et al., 2002). Hence, directors' remuneration might depend on whether they are, or are not, in a situation of conflict of interest with the firm, regardless of their effort and responsibilities in the board. The extent to which such directors are truly independent is central to the issue of whether they are able to exert an 'objective independent judgment' or not. The lack of real independence could facilitate the rise of corporate insiders' power (Jensen, Murphy \& Wruck, 2004).

In the assessment of director's independence, regulators have either adopted a 'rules-based' approach, by requiring companies to consider a non-executive director to be independent only when several formal criteria are met, or a 'principles-based' approach, by giving companies the possibility of evaluating a director as independent even when s(he) does not meet all the formal independence criteria. In the latter case, the board of directors evaluates the independence of each director and is requested to explain situations where they deem a director as independent 
even if the formal independence criteria are not fulfilled. The underlying logic reflects an optimal contracting view in that assessing independence as compliance with rules that define appropriate relationships undermines the link to ethical behaviour (Page \& Spira, 2005). Thus, if relationships or circumstances do not, and are not likely to, affect the director's judgement perhaps companies should not blindly apply the independence criteria (Karmel, 2014), as identified in the national corporate governance codes (Italian Code of Conduct, 2006, 2011; Combined Code, 2006; UK Corporate Governance Code, 2012). In line with this perspective, it is assumed that boards will use this flexibility to use their professional judgment in determining whether to declare their directors as independent.

However such flexibility, from a managerial power perspective (Bebchuk et al., 2002), provides the boards with an incentive to declare their directors as independent even when such an assessment might be considered dubious. In other words, the lack of fulfilment of the formal independence criteria set by the corporate governance codes (or other regulation) could affect the director's actual independence, despite the company stating that the director is independent in character and judgement. INEDs who have an interest at stake may behave differently from those who are fully independent because whilst they are deemed to be formally independent, in reality they may not be. Those INEDs may act in the interests of corporate insiders, collude with the CEO (or the controlling shareholder) and exercise their monitoring duties less efficiently (Melis, 2005; Clark, Wójcik \& Bauer, 2006).

Hence, according to a managerial power view, such INEDs may be paid significantly more than INEDs who do meet all the independence criteria, regardless of their level of visible 
effort and responsibilities, as a result of their lack of actual independence and potential to collude with corporate insiders.

H2: INED's remuneration will be negatively associated with the fulfilment of the independence criteria stated in the corporate governance codes.

\section{Research methodology}

\subsection{Sample and data}

In order to analyze INEDs' remuneration a sample composed of Italian and UK non-financial companies listed respectively on the Milan Stock Exchange and on the London Stock Exchange in the period 2007-2009 was selected. As firm size (Hempel \& Fay, 1994; Boyd, 1996; Marchetti \& Stefanelli, 2009; Andreas et al., 2012) and industry (Ely, 1991) are likely to affect directors' remuneration, the sample was selected so that UK and Italian firms were not significantly different from each other in terms of industry and size. By using a stratified random procedure the population is first divided into a number of parts or strata according to some characteristics, chosen to be related to the major variables being studied.

There were 235 Italian non-financial firms and 1557 non-financial UK firms listed in 2007, 2008 and 2009. Firms whose financial year-end was not the end of December were eliminated from the analysis, to ensure comparability of the results, leaving 220 Italian firms and 667 UK firms. Inside each of the two groups, the listed companies were stratified according to two-digit SIC industry code and market capitalization (as a proxy for firm size) at 31st December 2008. At this stage we had 220 potential pairs. After the matching procedure of each Italian firm with a UK 
firm with the same two-digit SIC code, and a similar market capitalization, 92 potential pairs had to be dropped, leaving 128 potential pairs. Then we eliminated companies that did not disclose any information about INEDs' remuneration or did not have any INEDs who served the firm throughout the whole financial year. A pair was eliminated from the sample only if both companies fell into at least one of those situations. If only one of the companies of the pair fell into at least one of the above mentioned situations we looked for another firm to match. This procedure led to a final sample composed of 91 Italian non-financial listed firms and 91 UK nonfinancial listed firms, with 546 firms' year observations and a total of 1733 INEDs' year observations.

Data on INEDs' remuneration, age, efforts and responsibilities, and board evaluation were handcollected from companies' annual reports and corporate governance reports. Data on INEDs' previous directorships were gathered from Thomson One Banker as were the data on firm's market capitalization and industry. Finally, firm's performance measures and financial leverage data were gathered from the Amadeus database.

\subsection{Data analysis methods}

The basis and the amounts of INEDs' remuneration were analysed by using descriptive statistics tools. In order to test our hypotheses we estimated a series of three-level hierarchical linear regression models with INEDs' remuneration as the dependent variable. We employed a multilevel hierarchical linear model with random intercept and random slope, as our sample is characterized by the presence of annual observations for each director $(\mathrm{j}, \mathrm{t})$ nested within directors (j), which in turn are nested within firms (i). The multilevel hierarchical linear model relates our control factors $\left(\mathrm{c}_{\mathrm{j}, \mathrm{i}, \mathrm{t}}\right)$, and our independent variables of interest $\left(\right.$ Effort $_{\mathrm{j}, \mathrm{i}, \mathrm{t}}$ and 
Independence $\mathrm{j}_{\mathrm{j}, \mathrm{i}, \mathrm{t}}$ ) to the remuneration of the INED $\mathrm{j}$ in firm $\mathrm{i}$ at time $\mathrm{t}\left(\right.$ Remuneration $\left._{\mathrm{j}, \mathrm{i}, \mathrm{t}}\right)$, by controlling for fixed-year effects $\left(\lambda_{t}\right)$, for firm-level random effects $u^{(1)}{ }_{i}$, and director-level

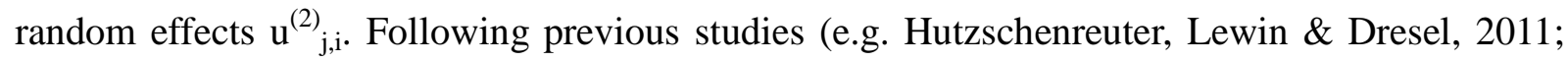
Merchant, 2012; Nicholson \& Salaber, 2013) we estimated our cross-sectional regressions separately for Italian and UK firms.

(1) Remuneration Ri,it $=\alpha_{0}+\beta_{1}$ Effort $_{j, i, t}+\beta_{2}$ Independence $_{j, i, t}+\gamma c_{j, i, t}+\lambda_{t}+Z_{i, j}^{(1)} u_{i}^{(1)}+Z_{i, j}^{(2)} u_{i, j}^{(2)}+\varepsilon_{j, i, t}$

At this stage, four INEDs' year observations were dropped as their remuneration was equal to zero. To check for multicollinearity we verified the level of correlation among the independent variables and the variance inflation factors (VIFs).

\subsection{Variables}

\subsubsection{Dependent variable.}

Following previous studies (e.g., Marchetti \& Stefanelli, 2009, Andreas et al 2012), our dependent variable (Remuneration) is the natural logarithm of the total remuneration received by an INED during a financial year $\left(^{2}\right)$, measured as the sum of total fees and performance-related pay $\left(^{3}\right)$ (used by some companies although not recognised as best practice).

\subsubsection{Independent variables.}

\footnotetext{
${ }^{2}$ The logarithm of the remuneration is used to reduce the level of heteroscedasticity in the dependent variable (e.g., Marchetti \& Stefanelli, 2009; Fernandes et al, 2013).

${ }^{3}$ Performance-related pay is equal to the sum of cash bonuses and gains realized from the exercise of share options or the award of shares.
} 
The amount of effort and responsibility that is observable to shareholders is likely to depend on the different tasks INEDs are required to do. Following previous literature (Hempel \& Fay, 1994; Cordeiro et al., 2000; Brick et al., 2006; Farrell et al., 2008; Marchetti \& Stefanelli, 2009; Engel et al., 2010), director's observable effort and responsibilities were measured as follows:

- "Chair", a dichotomous variable that equals 1 if the INED is the Chair of the Board during the financial year, and 0 otherwise

- "SID" (Senior Independent Director), a dichotomous variable that equals 1 if the INED serves as SID during the financial year, and 0 otherwise

- "Committees", number of board committees the INED sits on during the financial year;

- "Committees' chair", number of board committees chaired by the INED during the financial year.

- "Board attendance", number of board meetings attended by the INED during the financial year.

The presence of INEDs' potential conflicts of interest was estimated by considering whether firms abide by the corporate governance codes' formal criteria to assess non-executive directors' independence. The variable "Independence" is a dichotomous variable that equals 1 if the INED fulfilled all the independence criteria stated by the Corporate Governance Code, and 0 otherwise.

\subsubsection{Control variables.}

- "Firm size", measured as the natural logarithm of the total assets of the firm at the end of the year t-1. Larger firms are likely to be characterized by more complex activities with larger stakes involved (Bryan et al., 2000; Brick et al., 2006; Andreas et al., 2012). 
- "Financial leverage", measured as the ratio between the value of total debts and total assets at the end of the year t-1. The level of debt could influence the firm's need to select INEDs for monitoring executives and top management (Williamson, 1988; Brick et al., 2006).

- "Board evaluation", measured as 1 if the company conducts a board evaluation, and 0 otherwise. A formal board evaluation process aimed at evaluating whether directors are performing their duties efficiently could influence the level of INEDs' remuneration (Marchetti \& Stefanelli, 2009). In accordance with the results of the board evaluation process, INEDs could be rewarded/punished with an increase/decrease in their remuneration.

- "Firm Performance", measured as Total Shareholder Return. INEDs in firms that achieved higher performance in the market are likely to receive higher pay than those of firms whose performance was lower (Jensen \& Murphy, 1990).

- "Firm compliance", measured as 1 if the firm complied with the corporate governance codes for all INEDs, and 0 otherwise. It is used to control if a firm was compliant with the corporate governance codes formal independence criteria with respect to all INEDs.

- "INEDs' directorships", number of positions previously held as director in other companies, as INEDs with many directorships will have a strong expertise that will help him/her in performing better his/her activity, hence s(he) will be paid more (Carpenter, Sanders \& Gregersen, 2001).

- "INEDs' age", measured as the natural logarithm of the INEDs' age. It proxies as a general level of experience (Hogan \& McPheters, 1980; Marchetti \& Stefanelli, 2009).

- "Industry", measured as a set of dichotomous variables which equal 1 if the firm operated in the $i$ one-digit sic and 0 otherwise. Director's remuneration may reflect a need to conform to market expectations which could be predicted by examining industry traditions or peer references (Aguilera \& Jackson, 2003). 
- "Year", as a set of dichotomous variables which equal 1 if the remuneration refers to the $i$ year $(i=2007,2008,2009)$ and 0 otherwise. Used in order to control for year-effect.

\section{Empirical results}

\subsection{Univariate analysis}

The descriptive statistics for INEDs' remuneration are shown in Table 2. The 2007-2009 INEDs' remuneration trends are similar for Italy and the UK as they show a gradual increase from 2007 to 2009.

\section{INSERT TABLE 2}

The median and mean remuneration values are significantly higher in UK firms than in Italian firms ( $€ 63,073$ vs. $€ 42.853, \mathrm{p}<0.01$ ). This difference may be attributed to differences in efforts and responsibilities between INEDs in the UK and Italy. More specifically, the average level of effort and responsibilities of INEDs is significantly higher in UK firms than in Italian ones as UK INEDs sit on (and chair) a higher number of board committees, and are more frequently the Chair of the board or the SID (see Table 3). This disparity in role may be a consequence of the differences that exist between the two corporate systems in terms of relevance of the agency problem between executives and shareholders as well as overall development of the corporate governance best practices. Indeed, because of the presence of a controlling shareholder who is able to directly monitor executive directors, INEDs may have to exert less effort and have less responsibilities in Italian firms than in UK firms. Indeed, as also recognized by the Italian Code of Corporate Governance, the setting up of a nomination committee is not as important in Italy as in UK firms as potential candidates are usually chosen by the controlling shareholder in Italy. Moreover, in contrast to the UK where the Code of Corporate Governance recommends all listed 
firms to appoint a SID, in Italy such a recommendation is only directed to firms with either a dual CEO/Chair or a Chair who is also the controlling shareholder.

\section{INSERT TABLE 3}

Panel B in Table 3 reports the descriptive statistics at firm level. It shows that, compared to the UK firms, Italian firms are significantly more indebted and significantly more of them adopt the formal criteria stated by the national Corporate Governance Code in assessing directors' independence. In contrast, they are less likely to conduct board evaluations and recorded lower stock market performance.

Table 4 reports the correlations between all the variables used in the analysis for Italian firms (Panel A) and UK firms (Panel B).The first column in these tables reports the variance inflation factors (VIFs) for each explanatory variable. VIF values are low and the independent variables do not have correlations with each other greater than $|0.6|$, thus multicollinearity is unlikely to be a concern. As shown in Table 4, in both countries, INEDs' remuneration (our dependent variable) is positively and significantly correlated $(\mathrm{p}<0.01)$ with the number of board meetings attended by INEDs, INEDs' age, firm size and financial leverage, the implementation of a board evaluation, and the public utilities industry. In Italy only, INEDs' remuneration is also positively and significantly correlated $(\mathrm{p}<0.01)$ with the number of committees on which INEDs sit and the number of those they chair, as well as with INEDs' abidance by the corporate governance codes' formal independence criteria and the firm's compliance with the corporate governance code. In the UK, INEDs' remuneration is positively and significantly correlated $(p<0.01)$ with the chairperson position and the INEDs' previous directorships. On the contrary, it is negatively and 
significantly correlated $(\mathrm{p}<0.01)$ with the number of committees on which INEDs sit. This counter-intuitive finding is due to the fact that in the UK, chairpersons - who are paid significantly more than other INEDs - rarely sit on board committees. Indeed, as shown in the panel B of Table 4, in the UK the variables 'Chair' and 'Committee' are negatively and significantly correlated $(\mathrm{p}<0.01)$.

\section{INSERT TABLE 4}

\subsection{Multivariate analysis}

Table 5 reports the results of regression analysis for each country. For each country two models have been developed. In model 1 we included all INEDs, while in model 2 we excluded the INEDs who chaired the board. We excluded Chairs for the following reasons: firstly in the UK, the Chair's independence has to be evaluated differently from other INEDs, thus we need to exclude them in order to test hypothesis 2 ; secondly Chairs are usually paid significantly more than other non-executive directors and usually are less involved in the board's committees, thus the results could be affected by their inclusion in the sample.

\section{INSERT TABLE 5}

In both countries (see models 1 and 2 for Italy and models 3 and 4 for the UK in Table 5) the variables 'Chairperson', 'SID', and 'Board attendance' are positively and significantly related to INEDs' remuneration. This suggests that both UK and Italian firms design INEDs' remuneration by taking into account the roles which INEDs cover (as Chairperson or SID) and the effort they 
exert, in terms of number of board meetings they attended during the year. A significant difference between the UK and Italian firms emerges in the importance that committee positions have in determining the amount of INEDs' remuneration. In particular, the variable 'Committees' has a positive and significant influence on INEDs' remuneration in Italian firms, but not in the UK firms (see Table 5). By contrast, the variable 'Committees chair' is positively and significantly related to INEDs' remuneration in the UK firms, whilst having a positive, albeit not significant, influence in the Italian firms. These findings suggest that positions held by an INED on the board's committees influence INEDs' remuneration differently in the two countries. In Italy, INEDs are paid significantly more in accordance with the number of committees they sit on, while in the UK a higher remuneration is given to an INED according to the number of committees s/he chairs. Despite these differences, our findings show that in both countries INEDs' remuneration is positively and significantly related to INEDs' effort and responsibilities. Thus, $\mathrm{H} 1$ is supported.

On the other hand, $\mathrm{H} 2$ is supported, but only in the UK. Whilst we find that in both countries the variable 'independence' is negatively related to INEDs' remuneration, this relation is only statistically significant in the UK sample (see model 4). Thus in the UK, INEDs who do fulfil all the formal independence criteria stated by the Corporate Governance Code are paid significantly less than INEDs who do not.

In line with the descriptive statistics, multivariate analysis shows that in both countries INEDs' remuneration was significantly higher in 2009 , as the coefficient of the variable year 2009 is positive and significant. We also find that, in both countries, INEDs with a greater expertise, in 
terms of previously-held directorships, are paid significantly more, as well as those who served on the boards of larger firms and/or on the boards of firms which belong to the public utilities industry. In Italy INEDs' remuneration is also significantly higher in more indebted firms.

\subsection{Robustness tests}

We performed a number of additional analyses to support the robustness of our results.

First, we run all the regression models by considering only the fixed remuneration received by INEDs as the dependent variable. Results are consistent with those reported in Table 5. Second, we repeat our analysis using year-by-year annual data. For each year we obtain results qualitatively similar to those reported in Table 5. Third, to control for abnormal remuneration we run all the regression models by excluding INEDs whose remuneration was above the 99 percentile and under the 1 percentile. Results are consistent with those reported in Table 5. Fourth, in relation to the overall sample, because there was a lack of disclosure on some issues, in particular the number of board meetings INEDs attended during the company's financial year (see Table 3), we were not able to estimate all the independent variables for each observation. Therefore, we performed all the previous regression models by considering the independent variables that we were able to estimate for each of the 1733 observations. Results are consistent with the findings reported earlier. Finally, we performed an interactive regression model $\left({ }^{4}\right)$ that allows us to take into account the potential moderating role of country-level factors on the relationship between INEDs' remuneration and our measures of (i) INEDs' effort and

\footnotetext{
${ }^{4}$ The model used is:

Remuneration $_{j, i, t}=\alpha_{0}+\beta_{1}$ Effort $_{j, i, t}+\beta_{2}$ Independence $_{j, i, t}+\beta_{3}$ Country $+\beta_{4}\left(\right.$ Effort $_{j, i, t} \times$ Country $)+\beta_{5}\left(\right.$ Independence $_{j, i, t} \times$ Country $)+$ $+\gamma_{j, i, t}+\lambda_{t}+Z_{j, i}^{(1)} i, u_{i}^{(1)}+Z_{j, i}^{(2)} u_{i, j}^{(2)}+\varepsilon_{j, i, t}$

Where: Country equals 1 if the firm operates in Italy and 0 otherwise.
} 
responsibilities and (ii) INEDs' abidance by the corporate governance codes' formal independence criteria. We find that country-level factors have an influence on the relationship between INEDs' remuneration and his(her) observable effort and responsibilities, in terms of committee membership, as its influence on INEDs' remuneration is significantly stronger in Italy than in the UK. We do not find any significant difference between the two countries on the influence played by the other variables used to estimate INEDs' effort and responsibilities and INEDs' remuneration. Moreover, in line with the findings reported in Table 5, we find that the negative influence between INEDs' abidance by the corporate governance codes' formal independence criteria and their remuneration is significantly stronger in the UK than in Italy.

\section{Discussion and concluding remarks}

This study contributes to the understanding of INEDs' remuneration by adopting an agency theory framework. In particular, it analyses the extent to which both optimal contracting theory and managerial power perspectives of agency theory are able to explain INEDs' remuneration in two different institutional contexts, the UK and Italy, by investigating whether INEDs' remuneration reflects INEDs' effort and responsibilities that are observable by shareholders and/or INEDs' potential conflicts of interest. Our findings provide support for the view, previously brought to light in executive remuneration studies, that optimal contracting and managerial power perspectives do not necessarily represent competing explanations but 'points on a continuum of types of contracting arrangements that can be encompassed within agency theory' (Van Essen et al., 2014: 24). 
We show that INEDs' remuneration is mainly based on the observable effort they exert and their responsibilities within the board (e.g., board meeting attendance, role of chairperson of the board or of senior independent director). This supports an optimal contracting view of agency theory (e.g., Gomez-Mejia \& Balkin, 1992). INEDs' performance is an extremely difficult area for the principals (the shareholders) to measure and observe. In contrast, INEDs formal/functional roles within the board (e.g. chairpersonship, committee membership etc.) as well as their official participation in the board activities (e.g. board meeting attendance) represent informative proxies of the level of effort and responsibilities effectively exerted, as they are unequivocal and observable by the shareholders. This finding is in line with agency theory at it suggests that when direct monitoring is infeasible it is efficient to base the agent's (INEDs) remuneration on outcomes that the principals can observe (Holmström, 1979). Moreover this is consistent with what is considered as best practice in the corporate governance codes (e.g., Italian Code of Conduct, 2011, UK Corporate Governance Code, 2012), which are themselves strongly influenced by agency theory (Zattoni \& Cuomo, 2010).

Our study also reveals that INEDs are paid more when they do not fulfil all of the independence criteria stated by the corporate governance codes, after controlling for their observable effort and responsibilities, than those who do fulfil these criteria. The Italian and the UK Codes of Corporate Governance share the assumption that boards will use their professional judgment, independently from their directors, in determining whether to declare a director as independent, even when s/he does not meet all the independence criteria. Despite this underlying assumption, we find that such behaviour appears to be interpretable with the managerial power lens. This is because it seems to be associated with a potential collusion between such INEDs 
and the corporate insiders rather than the result of an effective and objective board test of independence which uses the discretion given to improve corporate governance. According to a managerial power perspective, directors with a potential conflict of interest (such as those who do not fulfil all of the independence criteria stated by the Codes of Corporate Governance) might collude with corporate insiders and help them in pursing their own interest rather those of shareholders. In such cases, directors who provide generosity to the corporate insiders find the latter reciprocating (Bebchuk et al., 2002).

This finding extends the literature on the managerial power perspective of agency theory, previously mainly focused on executive remuneration (e.g., Bebchuk et al, 2002; Van Essen, et al, 2014), by providing new insights on INEDs' remuneration. It also contributes to the existing regulatory debate about the choice of either a statutory regime or a flexible system on some governance issues (McNeil \& Li, 2006; Arcot, Bruno \& Faure-Grimaud, 2010; Fasterling, 2012), by providing new insights on the risks associated with a flexible system on the key corporate governance issue of INEDs. Moreover, by highlighting the potential implications of assessing directors' independence as compliance with rules, our study has attempted to answer the call of Aguilera and Cuervo-Cazurra (2009) for more careful examination of the content of the codes of corporate governance to help understand the soundness, or otherwise, of their recommendations.

Our study provides a number of contributions to the International Business literature. This study provides empirical evidence on the level and composition of INEDs' remuneration in listed firms that operate in two European countries, whilst the previous literature has mainly focused on US firms. Moreover, it contributes to understanding whether agency theory can be 
applied to very different institutional contexts (e.g., Eisenhardt, 1988; Aguilera \& Jackson, 2003; Gomez-Mejia \& Wiseman, 2007; Aguilera et al., 2008; Wiseman et al., 2012) and whether the effectiveness of corporate governance mechanisms predicted by agency theory are affected by institutional considerations (e.g., Bowe et al, 2010; Van Essen et al, 2012; Wiseman et al., 2012). The results show similarities between Italy and the UK in the limited use of performance-based remuneration for INEDs, but significant differences in terms of the amount paid. The very limited use of performance-based remuneration, which is in accordance with the good practices recommended by the Italian and UK Corporate Governance Codes, contrasts with the US evidence (Bhagat, Carey \& Elson, 1999; Cordeiro et al., 2000; Williams, 2005; Engel et al., 2010) where performance-based remuneration is highly diffused.

This significant difference could be attributed to the belief, shared by Italy and the UK, that performance-based remuneration could be detrimental for directors' independence (Italian Code of Conduct, 2006; 2011; UK Corporate Governance Code, 2012), a view which contrasts with the US underlying assumption that performance-based remuneration can reduce the agency problems between INEDs and shareholders by providing the former an incentive to effectively monitor executive directors (e.g., Shen, 2005). This pattern is consistent with the empirical studies on CEO remuneration which find a divide between US and European firms' practices (e.g., Conyon \& Murphy 2000; Fernandes et al., 2013).

We also find that UK firms paid their INEDs significantly more than Italian firms. Country-level institutional differences between Italy and the UK might provide an explanation for this finding, as they can affect both the overall amount paid and the INEDs role. The higher 
remuneration paid to INEDs by UK firms may be attributable to the fact that UK firms are more exposed to US financial influence than Italian firms and US influence tends to increase remuneration (Oxelheim \& Randøy, 2005). In addition, in contrast with the UK, Italy is characterized by listed firms with a more concentrated ownership structure and a higher debt ratio. These characteristics increase the monitoring undertaken by (controlling) shareholders and creditors. Therefore, INEDs might have to exert less effort and have fewer responsibilities in Italian firms than in UK firms. This in turn leads to a clear contrast with the higher INEDs' remuneration in the UK. Moreover, INEDs' reputational risks and personal liabilities are also influenced by the institutional context. In the UK, according to the Companies Act (2006), directors can be held personally liable for breach of duties and equal liabilities exist between executive directors and INEDs. By contrast, in Italy INEDs' liabilities are significantly lower as the 2004 Company Reform attributes most of them to executive directors. In addition, the UK is characterised by a higher level of legal protection of minority shareholders and a significant role played by takeovers (La Porta et al. 1997). Given that INEDs could require an increase in remuneration to offset the risks associated with exposure to potential liabilities, litigation costs and consequent higher responsibility (Linck et al., 2009; Aguir et al., 2013), this significant difference in INEDs' reputational risks and personal liabilities may explain why INEDs are paid significantly more in the UK than in Italy.

Despite such institutional differences, we found that the general criteria used by firms in the two countries to set INEDs' remuneration are largely the same. Both Italian and UK firms pay INEDs on the basis of their observable effort and responsibilities, although some differences do exist on the influence that the specific type of effort and responsibilities have in determining 
the amount of INEDs' remuneration. The essential agency problem seems to remain in both contexts because information asymmetry between shareholders and INEDs exists both in Italy and in the UK. INEDs always have more information than shareholders because of their proximity to the tasks and responsibilities to which they are assigned. To monitor agents' behaviour by basing INEDs' remuneration on their observable effort and responsibilities reflects a concern in any relationship that involves delegation (Gomez-Meja \& Wiseman, 2007), especially in a non-programmable job context, where direct supervision is infeasible. However, the different importance that is placed on committee positions and the presence of INEDs' potential conflicts of interest in determining the amount of INEDs' remuneration reveals that even though agency problems remain in both contexts, the explicit manifestation of these problems and ways to deal with them may vary depending on the institutional context (Wiseman et al., 2012). Therefore, our study supports the argument that agency theory should be complemented with an institution-based view.

As with any study, this one is not without its limitations. Firstly we examine INEDs' remuneration in two countries only and whilst the choice of Italy and the UK assured adequate between-country variation, enabling us to leverage the generalisability of the findings, a more comprehensive picture would be obtained by further study of additional countries. Secondly our dataset covers the period 2007-2009, future studies could encompass later periods. While these considerations impose some limitations on the interpretation of our results, they also offer exciting opportunities for future research in the area of INEDs' remuneration which is still considerably under-investigated. 
In spite of these limitations, this study nonetheless provides valuable insights and has a number of relevant practical and policymaking implications. First of all, our finding that firms rely on measures of effort and responsibilities that are observable to shareholders, rather than monitoring the INED's quality of performance as an independent performance outcome, provides new insights to practitioners when designing INEDs' remuneration. These new insights are important given that designing INEDs' remuneration is a job where direct supervision by principals is either not feasible or counter-productive. Second, our finding on the presence of potential collusion between INEDs and the corporate insiders when best practices are not fully enforced offers a new awareness to policymakers. It casts some doubt on the effectiveness of adopting non-binding criteria in order to assess non-executive directors' independence. It also leaves us with the important question of the extent to which INEDs can be relied on as an effective corporate governance mechanism and a measure of corporate governance quality (Adams \& Ferreira, 2007; Fich, 2005; Mura, 2007). This in turn also has important ramifications as it leads to questions about the effectiveness of other corporate governance devices which are expected to work on the basis of the assumed independence of directors (e.g., key board committees such as the audit/remuneration committees). Overall, this study extends the scant literature on INEDs' remuneration and its determinants and provides a contribution to the solution of the "enigma" of INEDs' remuneration. 


\section{References}

Adams, R., \& Ferreira, D. (2007). A theory of friendly boards. Journal of Finance, 62(1), 217250.

Adams, R., \& Ferreira, D. (2008). Do directors perform for pay? Journal of Accounting and Economics, 46, 154-171.

Aguilera R., \& Cuervo-Cazurra A. (2009). Codes of Good Governance, Corporate Governance: An International Review, 2009, 17(3), 376-387.

Aguilera, R., \& Jackson, G. (2003). The cross-national diversity of corporate governance: dimensions and determinants. Academy of Management Review, 28(3), 447-465.

Aguilera R., Filatotchev, I., H., Gospel, \& Jackson G. (2008), An Organizational Approach to Comparative Corporate Governance: Costs, Contingencies, and Complementarities. Organization Science, 19(3), 475-492.

Aguir, I., Burns, N., Mansi, S. A., \& Wald, J. K. (2014). Liability protection, director compensation, and incentives. Journal of Financial Intermediation, forthcoming.

Andreas, J., Rapp, M., \& Wolff, M. (2012). Determinants of director compensation in two-tier systems: evidence from German panel data. Review of Managerial Science, 6(1), 33-79.

Arcot, S., Bruno, V., \& Faure-Grimaud, A. (2010). Corporate governance in the UK: Is the comply or explain approach working?. International Review of Law and Economics, 30(2), 193201.

Austrian Code of Corporate Governance (2009). Austrian Working Group for Corporate Governance, Wien.

Bebchuk, L., Fried, J., \& Walker, D. (2002). Managerial Power and Rent extraction in the Design of Executive Compensation. University of Chicago Law Review, 69, 751-846.

Bender, R. (2004). Why Do Companies Use Performance-Related Pay for Their Executive Directors?. Corporate Governance: An International Review, 12(4), 521-533.

Bhagat, S., Carey, D., \& Elson, C. (1999). Director ownership, corporate performance, and management turnover. The Business Lawyer. (May), 885-919.

Bowe M., Filatotchev I., Marshall A. (2010), Integrating contemporary finance and international business research, International Business Review, 19, 435-445.

Boyd, B. (1996). Determinants of US outside director compensation. Corporate Governance: An International Review, 4(4), 202-211. 
Brick, I., Palmon, O., \& Waldet, J. (2006). CEO compensation, director compensation, and firm performance: Evidence of cronyism?. Journal of Corporate Finance, 12, 403-423.

Brown, K. (2007). New demands, better boards: rethinking director compensation in an era of heightened corporate governance. New York University Law Review, 82, 1102-1138.

Bryan, S., Hwang, L., Klein, A., \& Lilien, S. (2000). Compensation of Outside Directors: An Empirical Analysis of Economic Determinants, NYU Working Paper No. 2451/2745.

Cadbury, A. (1992), Report of the Committee on the Financial Aspects of Corporate Governance, London: Gee.

Carpenter, M., Sanders, G., \& Gregersen, H. (2001). Bundling Human Capital With Organizational Context: The Impact of International Assignment Experience on Multinational Firm Performance and CEO Pay. The Academy of Management Journal, 44(3), 493-511.

Certo T., Dalton, C., Dalton, D., \& Lester, R. (2008). Boards of Directors' Self Interest: Expanding for Pay in Corporate Acquisitions?. Journal of Business Ethics, 77, 219-230.

Cho, K., Huang, C., \& Padmanabhan, P. (2014), Foreign ownership mode, executive compensation structure, and corporate governance: Has the literature missed an important link? Evidence from Taiwanese firms. International Business Review, 23(2), 371-380.

Clark, G.L., Wójcik, D., \& Bauer, R. (2006). Geographically dispersed ownership and intermarket stock price arbitrage Ahold's crisis of corporate governance and its implications for global standards. Journal of Economic Geography, 6: 303-322.

Combined Code $(2006,2008)$. The Combined Code on Corporate Governance, London: FRC.

Conyon, M., \&. Murphy, K. (2000). The Prince and the Pauper? CEO Pay in the United States and United Kingdom. The Economic Journal, 110(467), F640-F671.

Cordeiro, J., Veliyath, R., \& Eramus, E. (2000). An empirical investigation of the determinants of outside director compensation. Corporate Governance: An International Review, 8(3), 268-279.

Dutch Corporate Governance Code (2008). Principles of good corporate governance and best practice provisions.

Eisenhardt, K. (1988). Agency- and Institutional-Theory Explanations: The Case of Retail Sales Compensation. The Academy of Management Journal, 31(3), 488-511.

Ely, K. (1991). Interindustry Differences in the Relation between Compensation and Firm Performance Variables. Journal of Accounting Research, 29(1), 37-58. 
Engel, E., Hayes, R., \& Wang, X. (2010). Audit committee compensation and the demand for monitoring of the financial reporting process. Journal of Accounting and Economics, 49(1-2), 136-154.

Fama, E., \& Jensen, M. (1983). Separation of ownership and control. Journal of Law and Economics, 26(2), 301-325.

Farrell, K., Friesen, G., \& Hersch, P. (2008). How do firms adjust director compensation?. Journal of Corporate Finance, 14, 153-162.

Fasterling, B. (2012). Development of Norms Through Compliance Disclosure. Journal of Business Ethics, 106(1), 73-87.

Fernandes, N., Ferreira, M., Matos, P., \& Murphy, K. (2013). Are U.S. CEOs Paid More? New International Evidence. Review of Financial Studies, 26 (2), 323-367.

Fich, E. (2005). Are some outside directors better than others? Evidence form director appointments by Fortune 1000 firms. Journal of Business, 78(5), 1943-1971.

Filatotchev, I., \& Allcock, D. (2010). Corporate Governance and Executive Remuneration: A Contingency Framework. The Academy of Management Perspectives, 24(1), 20-33.

German Corporate Governance Code (2009). Government Commission German Corporate Governance Code.

Gomez-Mejia, L., \& Balkin, D. (1992). Determinants of faculty pay: An agency theory perspective. Academy of Management Journal, 35, 921-955.

Gomez-Mejia, L. \& Wiseman, R. (2007). Does agency theory have universal relevance? A reply to Lubatkin, Lane, Collin, and Very. Journal of Organizational Behavior, 28(1), 81-88.

Hahn, P., \& Lasfer, M. (2011). The compensation of non-executive directors: rationale, form, and findings. Journal of Management and Governance, 15(4), 589-601.

Heidrick \& Struggles (2009). CEO \& Board practice, Chicago: Heidrick \& Struggles International.

Hempel, P., \& Fay, C. (1994). Outside director compensation and firm performance. Human Resource Management, 33(1), 111-133.

Hogan, T.D., \& McPheters, D. (1980). Executive compensation: Performance versus personal characteristics. Southern Economic Journal, 46, 1060-1068.

Holmström, B. (1979). Moral Hazard and Observability. The Bell Journal of Economics, 10(1), 74-91. 
Hutzschenreuter, T., Lewin, A., \& Dresel, S. (2011). Governance modes for offshoring activities: A comparison of US and German firms. International Business Review, 20(3), 291-313

ICGN (2010). Non-executive Director Remuneration Policy and Guidelines. London: ICGN.

Italian Code of Conduct, (2006, 2011). Borsa Italiana, Milan.

Jensen, M., \& Murphy, K. (1990). Performance pay and top management incentive. Journal of Political Economy, 98(2), 225-264.

Jensen, M., Murphy, K., \& Wruck, E. (2004). Remuneration: Where we've been, how we got to here, what are the problems, and how to fix them. ECGI Finance Working Paper N. 44.

Johanson, D. \& Østergren, K. (2010). The Movement Toward Independent Directors on Boards: A Comparative Analysis of Sweden and the UK. Corporate Governance: An International Review, 18(6), 527-539.

Johnson S., La Porta R., Lopez-De-Silanes F. \& Shleifer A. (2000), Tunneling, American Economic Review Papers and Proceedings 90 (2), 22-27.

Karmel, R.S. (2014). Is the Independent Director Model Broken?. Seattle University Law Review, 37(2), 775-813.

La Porta, R., Lopez de Silanes, F., Shleifer, A., \& Vishny, R. (1997). Legal Determinants of External Finance. Journal of Finance, 52(2), 1131-1150.

Lazar, C., Metzner, Y., Rapp M.S., \& Wolff, M. (2014). Remuneration of Non-Executive Directors in German Listed Firms: An Empirical Analysis from a Practitioners' Perspective, Accounting, Economics and Law, 4(2), 1-16.

Linck, J., Netter, J., \& Yang, T. (2009). Effects and Unintended Consequences of the SarbanesOxley Act on Corporate Boards, Review of Financial Studies, 22(8), 3287-3328.

Lorsch, J., \& MacIver, E. (1989). Pawns and Potentates: the reality of America's corporate boards. Boston: Harvard Business School Press.

Mace M., 1971, Directors: Myth and reality. Boston: Harvard Business School Press.

Magnan, M., St-Onge, S., \& Gélinas, P. (2010), Director compensation and firm value: A research synthesis. International Journal of Disclosure and Governance,7, 28-41.

Mallin, C.A. (2010). Corporate Governance, Oxford: Oxford University Press.

Marchetti, P., \& Stefanelli, V. (2009). Does the compensation level of outside director depend on its personal profile? Some evidence from UK. Journal of Management and Governance, 13, $325-354$. 
McNeil, I., \& Li, X. (2006). "Comply or Explain": market discipline and non-compliance with the Combined Code. Corporate Governance: An International Review, 14(5), 486-496.

Melis, A. (2000). Corporate Governance in Italy. Corporate Governance: An International Review, 8(4), 347-355.

Melis, A. (2005). Corporate Governance Failures: to what extent is Parmalat a particularly Italian Case?. Corporate Governance: An International Review, 13(4), 478-488.

Melis, A., \& Gaia, S. (2011). Corporate governance in Italy: normative developments vs. actual practices, in C. Mallin (Eds), Handbook on International Corporate Governance, 2nd edition (pp. 59-92), Cheltenham: Elgar.

Merchant, H. (2012). The characteristics and stock-market performance of international joint ventures located in three host-country groups: An extension and empirical validation. International Business Review, 21(6), 1173-1189.

Minichilli, A., Zattoni, A., Nielsen, S., \& Huse, M. (2012). Board task performance: An exploration of micro- and macro-level determinants of board effectiveness. Journal of Organizational Behavior, 33, 193-215.

Mura, R. (2007). Firm Performance: Do Non-Executive Directors Have Minds of their Own? Evidence from UK Panel Data. Financial Management, 36(3), 81-112.

Nicholson, R., \& Salaber, J. (2013). The motives and performance of cross-border acquirers from emerging economies: Comparison between Chinese and Indian firms. International Business Review 22(6) , 963-980.

Oxelheim L., Randøy T. (2005), The Anglo-American financial influence on CEO compensation in non-Anglo-American firms, Journal of International Business Studies, 36, 470-483.

Page, M., \& Spira, L. (2005). Ethical codes, independence and the conservation of Ambiguity. Business Ethics: A European Review, 14(3), 301-316.

RiskMetrics (2009). Study on Monitoring and Enforcement Practices in Corporate Governance in the Member States. Brussels: RiskMetrics.

Ronen, J., Tzur, J., \& Yaari, V. (2006). The Effect of Directors' Equity Incentives On Earnings Management. Journal of Accounting and Public Policy, 25(4), 359-389.

Shen, W. (2005). Improve board effectiveness: the need for incentives. British Journal of Management, 16, 81-89.

Spanish Unified Good Governance Code (2006). Madrid: Comision Nacional del Mercado de Valores. 
Tosi, H., \& Gomez-Mejia, L. (1989). The Decoupling of CEO Pay and Performance: An Agency Theory Perspective. Administrative Science Quarterly, 34(2), 169-189.

UK Corporate Governance Code, 2012, London: FRC.

Van Essen M., Heugens P., Otten J. \&Van Oosterhout J. (2012), An institution-based view of executive compensation: A multilevel meta-analytic test, Journal of International Business Studies, 43, 396-423.

Van Essen, M., Otten, J., \& Carberry, E. J. (2014). Assessing managerial power theory: A metaanalytic approach to understanding the determinants of CEO compensation. Journal of Management, forthcoming.

Volpin, P. (2002). Governance with poor investor protection. Evidence from top executive turnover. Journal of Financial Economics, 64(1), 61-90.

Weimer, J., \& Pape J. (1999). A Taxonomy of Systems of Corporate Governance. Corporate Governance: An International Review, 7(2), 152-166.

Williamson, O. (1988). Corporate finance and corporate governance, Journal of Finance,43(3), 567-591.

Wiseman, R., Cuevas-Rodríguez, G., \& Gomez-Mejia, L. (2012). Towards a social theory of agency. Journal of Management Studies, 49(1), 202-222.

Yermack, D. (2004). Remuneration, Retention and Reputation Incentives for Outside Directors. Journal of Finance, 59, 2281-2308.

Zattoni, A. (1999). The Structure of Corporate Groups: The Italian Case. Corporate Governance: An International Review,7(1), 38-48.

Zattoni, A., \& Cuomo F. (2010). How Independent, Competent and Incentivized Should Nonexecutive Directors Be? An Empirical Investigation of Good Governance Codes. British Journal of Management, 21(1), 63-79. 


\title{
Table 1 - Definition of independence according to the Italian and the UK Corporate Governance Codes
}

\author{
ITALIAN CODE OF CONDUCT $\quad$ UK CORPORATE GOVERNANCE CODE
}

Relationships or circumstances relevant to evaluate director independence include whether the director:

\begin{tabular}{|c|c|}
\hline $\begin{array}{l}\text { controls...the issuer [even] through subsidiaries, trustees, } \\
\text { or...third party...; }\end{array}$ & represents a significant shareholder \\
\hline $\begin{array}{l}\text { is, or has been in the preceding three fiscal years, a } \\
\text { relevant representative of the issue...; } \\
\text { has... a significant commercial, financial or professional } \\
\text { relationship [with the issuer]...; }\end{array}$ & $\begin{array}{l}\text { has, or has had within the last three years, a material } \\
\text { business relationship with the company either directly, } \\
\text { or as a partner, shareholder, } \\
\text { director or senior employee of a body that has such a } \\
\text { relationship with the company; }\end{array}$ \\
\hline $\begin{array}{l}\text { receives a significant additional remuneration [from the } \\
\text { issuer]...; }\end{array}$ & $\begin{array}{l}\text { has received or receives additional remuneration from } \\
\text { the company apart from a director's fee, participates in } \\
\text { the company's share option or a performance-related } \\
\text { pay scheme, or is a member of the company's pension } \\
\text { scheme; }\end{array}$ \\
\hline $\begin{array}{l}\text { was a director of the issuer for more than nine years in } \\
\text { the last twelve years...; }\end{array}$ & $\begin{array}{l}\text { has served on the board for more than nine years from } \\
\text { the date of their first election. }\end{array}$ \\
\hline $\begin{array}{l}\text { is vested with the executive director office in another } \\
\text { company in which an executive director of the issuer } \\
\text { holds the office of director; }\end{array}$ & $\begin{array}{l}\text { holds cross-directorships or has significant links with } \\
\text { other directors through involvement in other } \\
\text { companies or bodies; }\end{array}$ \\
\hline \multicolumn{2}{|l|}{$\begin{array}{l}\text { is [a] shareholder or quotaholder or director of [an] } \\
\text { entity belonging to the same network as the company } \\
\text { appointed for the accounting audit of the issuer; }\end{array}$} \\
\hline is a close relative of a person [above].... & $\begin{array}{l}\text { has close family ties with any of the company's advi } \\
\text { directors or senior employees; }\end{array}$ \\
\hline
\end{tabular}


Table 2 - Descriptive statistics of INEDs' remuneration (in euros) in 2007-2009

\begin{tabular}{cccccccc}
\hline \multirow{2}{*}{2007} & & Obs & Mean & Median & Min & Max & Std. Dev. \\
& ITA & 284 & 41,096 & 30,000 & 1,000 & 178,000 & 35,211 \\
& UK & 286 & 59,400 & 48,074 & - & 522,488 & 51,024 \\
\hline \multirow{2}{*}{2008} & ITA & 281 & 41,590 & 30,500 & 1,000 & 173,000 & 34,618 \\
& UK & 284 & 64,036 & 49,327 & - & 569,296 & 56,125 \\
\hline \multirow{2}{*}{2009} & ITA & 291 & 45,786 & 34,500 & 2,080 & 368,179 & 41,731 \\
& UK & 307 & 65,605 & 51,569 & - & 569,296 & 55,919 \\
\hline \multirow{2}{*}{ Total period } & ITA & 856 & 42,853 & 31,000 & 1,000 & 368,179 & 37,390 \\
& UK & 877 & 63,073 & 50,605 & - & 569,296 & 54,442 \\
\hline
\end{tabular}

Notes: UK INEDs' remuneration was converted to Euros using purchasing power parity (PPP) (OECD, 2011). PPP rate Euro/Pound: 1.2651 calculated at December of 2007.

OECD (2011), Prices and purchasing power parities (PPP), http://www.oecd.org/std/prices-ppp/ 
Table 3 - Descriptive statistics of the sample

\begin{tabular}{|c|c|c|c|c|c|c|c|}
\hline \multicolumn{8}{|c|}{ Panel A: Descriptive statistics for INED characteristics } \\
\hline & \multicolumn{3}{|c|}{ ITA } & \multicolumn{3}{|c|}{ UK } & \multirow[b]{2}{*}{ Difference of means } \\
\hline & No obs & Mean & Std. Dev. & No obs & Mean & Std. Dev. & \\
\hline Chair & 856 & 0.01 & 0.18 & 877 & 0.10 & 0.2975 & $-0.09 * * *$ \\
\hline Committees & 856 & 1.49 & 0.94 & 877 & 2.53 & 0.73 & $-1.04 * * *$ \\
\hline Committees' chair & 856 & 0.32 & 0.57 & 877 & 0.72 & 0.64 & $-0.40 * * *$ \\
\hline SID & 856 & 0.12 & 0.33 & 877 & 0.23 & 0.42 & $-0.11 * * *$ \\
\hline Board attendance & 772 & 8.02 & 4.11 & 763 & 8.33 & 2.46 & $-0.31 *$ \\
\hline INED's directorships (a) & 856 & 1.99 & 2.06 & 877 & 2.24 & 2.44 & $-0.25 * *$ \\
\hline INED's age (a) & 853 & 59.50 & 11.31 & 870 & 58.85 & 7.15 & $-0.65 *$ \\
\hline \multirow[t]{4}{*}{ Independence } & 856 & 0.88 & 0.32 & 877 & 0.85 & 0.36 & $0.03 * *$ \\
\hline & \multicolumn{7}{|c|}{ Panel B: Descriptive statistics for firm characteristics } \\
\hline & & ITA & & & UK & & \\
\hline & No Obs & Mean & Std. Dev. & No obs & Mean & Std. Dev. & Difference of means \\
\hline Firm size (a) (b) & 273 & 4,261 & 16,700 & 273 & 2,803 & 16,800 & 1,457 \\
\hline Financial leverage & 273 & 0.60 & 0.18 & 273 & 0.53 & 0.26 & $0.07 * * *$ \\
\hline Board evaluation & 273 & 0.50 & 0.50 & 273 & 0.68 & 0.47 & $-0.18 * * *$ \\
\hline Firm performance & 269 & -0.12 & 0.47 & 269 & -0.04 & 0.50 & $-0.08 *$ \\
\hline Firm compliance & 273 & 0.73 & 0.44 & 273 & 0.59 & 0.49 & $0.14 * * *$ \\
\hline
\end{tabular}

Notes:

(a) Descriptive statistics are calculated without the logarithm; (b) Firm size is expressed in millions of Euros. Legend: * Significance at $10 \%$ level; $* *$ Significance at $5 \%$ level; *** Significance at $1 \%$ level 
Table 4 - Pearson correlation matrix

\begin{tabular}{|c|c|c|c|c|c|c|c|c|c|c|c|c|c|c|c|c|c|c|c|c|c|}
\hline & VIF & 1 & 2 & 3 & 4 & 5 & 6 & 7 & 8 & 9 & 10 & 11 & 12 & 13 & 14 & 15 & 16 & 17 & 18 & 19 & 20 \\
\hline \multirow{2}{*}{\multicolumn{22}{|c|}{ Panel A: Italy }} \\
\hline 1 Remuneration & & & & & & & & & & & & & & & & & & & & & \\
\hline 2 Chair & 1.10 & -0.02 & 1 & & & & & & & & & & & & & & & & & & \\
\hline 3 Committees & 1.29 & $0.20 * * *$ & $-0.07 * *$ & 1 & & & & & & & & & & & & & & & & & \\
\hline 4 Committees' chair & 1.29 & $0.11 * * *$ & -0.05 & $0.33 * * *$ & 1 & & & & & & & & & & & & & & & & \\
\hline $5 \mathrm{SID}$ & 1.27 & 0.05 & -0.04 & $0.23 * * *$ & $0.37 * * *$ & 1 & & & & & & & & & & & & & & & \\
\hline 6 Board attendance & 1.44 & $0.51 * * *$ & -0.01 & $0.12 * * *$ & $0.10 * * *$ & $=-0.05$ & 1 & & & & & & & & & & & & & & \\
\hline 7 Independence & 1.80 & $0.21 * * *$ & $-0.14 * * *$ & $0.14 * * *$ & $0.08 * *$ & 0.03 & $0.20 * * *$ & 1 & & & & & & & & & & & & & \\
\hline 8 Firm size & 1.12 & $0.62 * * *$ & $-0.10 * * *$ & $-0.10 * * *$ & -0.05 & $-0.10 * * *$ & $0.39 * * *$ & $0.06 *$ & 1 & & & & & & & & & & & & \\
\hline 9 Financial leverage & 1.31 & 0.33 *** & -0.03 & 0.03 & $0.08^{* *}$ & -0.04 & $0.25 * * *$ & $0.20 * * *$ & $0.28 * * *$ & 1 & & & & & & & & & & & \\
\hline 10 Board evaluation & 1.92 & $0.28 * * *$ & 0.04 & $-0.10 * * *$ & 0.02 & -0.01 & $0.09 * *$ & $0.07 *$ & $0.42 * * *$ & $0.17 * * *$ & 1 & & & & & & & & & & \\
\hline 11 Firm performance & 1.23 & -0.02 & -0.03 & $-0.07 * *$ & -0.02 & -0.03 & 0.01 & 0.06 & $0.06 *$ & -0.04 & $-0.06 *$ & 1 & & & & & & & & & \\
\hline 12 Firm compliance & 1.31 & $0.15 * * *$ & $-0.08 * *$ & $0.17 * * *$ & $0.12 * * *$ & $0.10 * * *$ & $0.08 * *$ & $0.57 * * *$ & $-0.13 * * *$ & $0.17 * * *$ & -0.02 & 0.03 & 1 & & & & & & & & \\
\hline 13 INED's age & 1.90 & $0.13 * * *$ & $0.12 * * *$ & -0.03 & -0.01 & 0.05 & 0.03 & $-0.18 * * *$ & $0.11 * * *$ & -0.01 & 0.00 & -0.01 & $-0.13 * * *$ & 1 & & & & & & & \\
\hline 14 INED's directorship & 2.13 & 0.01 & -0.05 & 0.02 & $0.09 * * *$ & $0.08 * *$ & $-0.16 * * *$ & $-0.18 * * *$ & $0.13^{* * * *}$ & -0.01 & $0.13 * * *$ & 0.00 & $-0.18 * * *$ & $0.13 * * *$ & 1 & & & & & & \\
\hline 15 year 2008 & 1.54 & $\begin{array}{l}0.02 \\
-0.02 \quad r\end{array}$ & 0.00 & 0.04 & 0.03 & 0.03 & $-0.07 *$ & 0.00 & -0.02 & -0.01 & -0.01 & 0.08 ** & 0.02 & 0.00 & 0.00 & 1 & & & & & \\
\hline 16 year 2009 & 2.53 & 0.05 & -0.02 & -0.01 & -0.01 & -0.02 & -0.02 & -0.03 & $0.06^{*}$ & $0.10 * * *$ & $0.08 * *$ & $-0.60 * * *$ & -0.04 & 0.04 & 0.01 & $-0.50 * * *$ & 1 & & & & \\
\hline 17 Light manufacturing & 1.70 & $-0.07 * *$ & 0.05 & $-0.10 * * *$ & $-0.08 * *$ & $-0.08 * *$ & 0.01 & $-0.22 * * *$ & $0.06 *$ & -0.05 & 0.10 *** & $-0.06 *$ & $-0.34 * * *$ & 0.01 & $0.09 * * *$ & 0.00 & 0.03 & 1 & & & \\
\hline 18 Heavy manufacturing & 1.92 & 0.05 & $-0.06 *$ & $0.17 * * *$ & $0.07 * *$ & $0.19 * * *$ & -0.06 & 0.00 & 0.05 & 0.03 & 0.01 & 0.03 & $-0.17 * * *$ & $0.14 * * *$ & $0.16 * * *$ & $\begin{array}{l}0.01 \\
-0.01\end{array}$ & $0.01-(-12-3$ & $0.25 * * *$ & 1 & & \\
\hline 19 Public Utilities & 1.92 & 0.31 *** & 0.06 * & $-0.09 * *$ & -0.04 & $-0.12 * * *$ & $0.29 * * *$ & $0.12 * * *$ & $0.32 * * *$ & $0.06 *$ & $0.21 * * *$ & -0.01 & $0.24 * * *$ & -0.01 & $-0.31 * * *$ & 0.02 & $-0.02-(4)$ & $0.15 * * *$ & $-0.27 * * *$ & 1 & \\
\hline \multirow[t]{2}{*}{20 Services } & 1.50 & $-0.07 * *$ & 0.03 & $0.08 * *$ & $0.08 * *$ & $0.07 * *$ & -0.04 & -0.02 & $-0.24 * * *$ & $0.07 *$ & $-0.09 * * *$ & $-0.12 * * *$ & 0.05 & -0.06 & 0.05 & 0.00 & $-0.01-(1)-1-1$ & $0.16 * * *$ & $-0.28 * * *$ & $-0.17 * * *$ & 1 \\
\hline & $\mathrm{VIF}$ & 1 & 2 & 3 & 4 & 5 & 6 & 7 & 8 & 9 & 10 & 11 & 12 & 13 & 14 & 15 & 16 & 17 & 18 & 19 & $\frac{20}{20}+3 x-10$ \\
\hline \multicolumn{22}{|l|}{ Panel B: UK } \\
\hline 1 Remuneration & & 1 & & & & & & & & & & & & & & & & & & & \\
\hline 2 Chair & 1.18 & $0.50 * * *$ & 1 & & & & & & & & & & & & & & & & & & \\
\hline 3 Committees & 1.16 & $-0.10 * * *$ & $-0.16 * * *$ & 1 & & & & & & & & & & & & & & & & & \\
\hline 4 Committees' chair & 1.29 & 0.04 & $0.12 * * *$ & $0.22 * * *$ & 1 & & & & & & & & & & & & & & & & \\
\hline 5 SID & 1.31 & $\begin{array}{l}0.04 \\
-0.04\end{array}$ & $-0.14 * * *$ & $0.22 * * *$ & $0.35 * * *$ & 1 & & & & & & & & & & & & & & & \\
\hline 6 Board attendance & 1.28 & $0.17 * * *$ & $0.08 * *$ & $0.09 * *$ & 0.03 & 0.04 & 1 & & & & & & & & & & & & & & \\
\hline 7 Independence & 1.40 & 0.04 & $-0.07 *$ & 0.04 & -0.04 & $-0.08 * *$ & $0.11 * * *$ & 1 & & & & & & & & & & & & & \\
\hline 8 Firm size & 1.20 & $0.47 * * *$ & $-0.07 *$ & $0.09 * * *$ & $-0.12 * * *$ & 0.04 & $0.17 * * *$ & $0.13 * * *$ & 1 & & & & & & & & & & & & \\
\hline 9 Financial leverage & 1.28 & 0.15 *** & -0.01 & 0.05 & 0.02 & $0.07 * *$ & $0.15 * * *$ & $0.10 * * *$ & $0.25 * * *$ & 1 & & & & & & & & & & & \\
\hline 10 Board evaluation & 1.48 & $0.19 * * *$ & $-0.09 * * *$ & $0.10 * * *$ & $-0.08 * *$ & $0.14 * * *$ & $0.26 * * *$ & $0.11 * * *$ & $0.48 * * *$ & $0.22 * * *$ & 1 & & & & & & & & & & \\
\hline 11 Firm performance & 1.44 & 0.01 & 0.01 & 0.00 & 0.01 & -0.01 & 0.04 & 0.01 & 0.03 & -0.04 & -0.04 & 1 & & & & & & & & & \\
\hline 12 Firm compliance & 1.24 & -0.04 & -0.02 & $0.08 * *$ & -0.03 & 0.02 & $0.17 * * *$ & $0.49 * * *$ & $-0.08 * *$ & 0.05 & 0.02 & -0.04 & 1 & & & & & & & & \\
\hline 13 INED's age & 1.63 & $0.14 * * *$ & 0.02 & -0.01 & $0.07 * *$ & $0.17 * * *$ & -0.05 & $-0.20 * * *$ & $0.17 * * *$ & 0.02 & $0.17 * * *$ & 0.03 & $-0.12 * * *$ & 1 & & & & & & & \\
\hline 14 INED's directorship & 1.60 & $0.27 * * *$ & 0.01 & 0.01 & 0.02 & 0.15 *** & $0.27 * * *$ & 0.00 & $0.33^{* * * *}$ & 0.11 *** & $0.21 * * *$ & -0.01 & -0.03 & $0.14 * * *$ & 1 & & & & & & \\
\hline 15 year 2008 & 1.53 & 0.01 & 0.00 & -0.01 & 0.01 & 0.00 & $-0.10 * * *$ & 0.00 & 0.02 & -0.05 & -0.02 & $0.06 *$ & 0.00 & 0.01 & 0.00 & 1 & & & & & \\
\hline 16 year 2009 & 2.16 & 0.03 & 0.01 & 0.03 & -0.01 & -0.01 & 0.06 & 0.01 & -0.01 & 0.05 & 0.04 & $-0.54 * * *$ & 0.02 & 0.05 & 0.05 & $-0.51 * * *$ & 1 & & & & \\
\hline 17 Light manufacturing & 1.81 & 0.04 & 0.04 & $-0.08 * *$ & -0.05 & 0.01 & 0.00 & $-0.16 * * *$ & $0.09 * * *$ & -0.10 *** & $0.11 * * *$ & -0.04 & $-0.34 * * *$ & 0.00 & -0.05 & 0.00 & -0.01 & 1 & & & \\
\hline 18 Heavy manufacturing & 2.20 & $\begin{array}{r}0.04 \\
-0.02\end{array}$ & 0.00 & $\begin{array}{l}-0.04 \\
-0.04 \\
-1\end{array}$ & $-0.08 * *$ & -0.02 & $0.12 * * *$ & $0.06 *$ & -0.05 & $-0.25 * * *$ & $0.13 * * *$ & $0.09 * *$ & $0.21 * * *$ & $0.09 * * *$ & $0.12 * * *$ & 0.00 & $0.00-1$ & $0.32 * * *$ & 1 & & \\
\hline 19 Public Utilities & 1.73 & $0.27 * * *$ & 0.00 & $0.09 * * *$ & 0.02 & -0.05 & 0.03 & $0.06 *$ & $0.29 * * *$ & $0.19^{* * * *}$ & 0.00 & 0.01 & -0.02 & -0.01 & $0.16 * * *$ & 0.00 & $0.01-($ & $0.18 * * *$ & $-0.30 * * *$ & 1 & \\
\hline 20 Services & 1.52 & $-0.12 * * *$ & $-0.06 *$ & 0.00 & $0.06 *$ & 0.02 & $-0.08 * *$ & $0.06 *$ & $-0.28 * * *$ & 0.19 *** & $=-0.25 * * *$ & -0.03 & $0.14 * * *$ & 0.02 & -0.07 & 0.01 & $0.00-1$ & $0.18 * * *$ & $-0.29 * * *$ & $-0.17 * * *$ & 1 \\
\hline
\end{tabular}

Notes: Legend: * Significance at $10 \%$ level; $* *$ Significance at $5 \%$ level $; * * *$ Significance at $1 \%$ level 
Table 5 - Results on the association between INEDs' remuneration (dependent variable) and INEDs effort, responsibilities and potential conflict of interest.

\begin{tabular}{|c|c|c|c|c|c|c|c|c|}
\hline \multirow[b]{3}{*}{ Chair } & \multicolumn{4}{|c|}{ ITALY } & \multicolumn{4}{|c|}{ UK } \\
\hline & \multicolumn{2}{|c|}{ Model 1} & \multicolumn{2}{|c|}{ Model 2} & \multicolumn{2}{|c|}{ Model 3} & \multicolumn{2}{|c|}{ Model 4} \\
\hline & 4.38 & $* * *$ & & & 19.08 & $* * *$ & & \\
\hline Committees & 6.47 & $* * *$ & 6.60 & $* * *$ & -3.79 & $* * *$ & 1.61 & \\
\hline Committees' chair & 0.93 & & 0.93 & & 2.79 & $* * *$ & 2.47 & $* * *$ \\
\hline SID & 2.17 & $* *$ & 2.16 & $* *$ & 0.04 & & 1.71 & $* *$ \\
\hline Board attendance & 3.75 & $* * *$ & 3.65 & $* * *$ & -0.41 & & 1.73 & $* *$ \\
\hline Independence & & & -0.48 & & & & -2.15 & $* *$ \\
\hline Firm size & 2.03 & $* *$ & 1.97 & $* *$ & 6.19 & $* * *$ & 5.61 & $* * *$ \\
\hline Financial leverage & 3.15 & $* * *$ & 3.12 & $* * *$ & -0.11 & & 0.37 & \\
\hline Board evaluation & 2.62 & $* * *$ & 2.62 & $* * *$ & 0.45 & & -0.31 & \\
\hline Firm performance & -0.48 & & -0.37 & & -0.60 & & -0.10 & \\
\hline Firm compliance & 1.40 & & 1.39 & & 0.62 & & 0.00 & \\
\hline INED's age & 1.28 & & 1.20 & & 2.37 & $* *$ & 1.49 & \\
\hline INED's directorships & 2.05 & $* *$ & 1.95 & $*$ & 2.08 & $* *$ & 1.69 & $* *$ \\
\hline year 2008 & 1.08 & & 1.17 & & 0.90 & & 2.14 & $* *$ \\
\hline year 2009 & 1.72 & $*$ & 1.77 & $*$ & 0.86 & & 2.14 & $* *$ \\
\hline Light manufacturing & 0.40 & & 0.44 & & 0.86 & & 1.67 & $*$ \\
\hline Heavy manufacturing & 0.62 & & 0.66 & & 0.56 & & 1.00 & \\
\hline Public Utilities & 2.50 & $*$ & 2.51 & $* *$ & 3.68 & $* * *$ & 3.95 & $* * *$ \\
\hline Services & -0.42 & & -0.32 & & 0.89 & & 1.25 & \\
\hline Constant & 13.85 & $* * *$ & 13.85 & $* * *$ & -3.06 & $* * *$ & -2.21 & $* *$ \\
\hline No Obs (b) & 765 & & 755 & & 739 & & 664 & \\
\hline Wald chi2 & 180 & $* * *$ & 159 & $* * *$ & 622 & $* * *$ & 130 & $* * *$ \\
\hline LR test (chi2) & 815 & $* * *$ & 806 & $* * *$ & 476 & $* * *$ & 342 & $* * *$ \\
\hline
\end{tabular}

Notes: The table presents the z-value.

Legend: * Significance at $10 \%$ level; ** Significance at $5 \%$ level; *** Significance at $1 \%$ level 